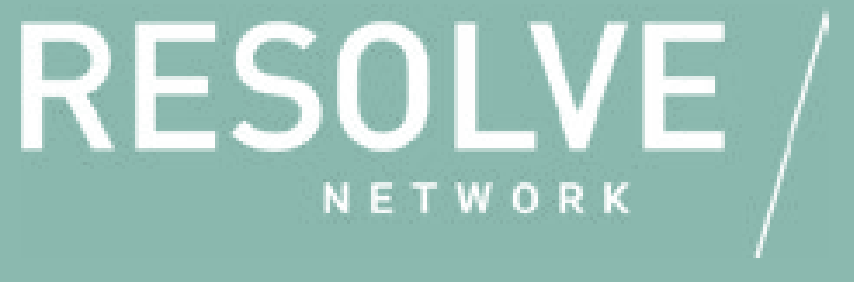

\title{
POLICY/NOTE
}

NOVEMBER 2019

\section{LINKING P/CVE \& ILLICIT ARMS FLOWS IN AFRICA}

\author{
NICOLAS FLORQUIN
}

COMMUNITY-BASED ARMED GROUPS SERIES

\section{The synergies between the fields of small arms control and P/CVE}

\author{
are critical, yet only tangentially explored.
}

\section{FAST FACTS}

$\rightarrow$ While some illicit small arms and light weapons in Africa are trafficked from other regions, there are prominent sources within the continent itself.

$\rightarrow$ Counter-trafficking interventions need to consider the livelihoods of border and transit communities, while also recognizing the shorter-term imperative of preventing violent extremist actors' access to deadly weaponry.

$\rightarrow$ Purely security-centered counter-trafficking approaches risk pushing border and transit communities towards criminality and, potentially, towards facilitating violent extremism.

\section{Context}

Small arms and light weapons are among the main instruments of conflict and violence, including violent extremism, in Africa. The member states of the African Union ( $A U$ ) have acknowledged this link by prioritizing both small arms control and preventing and countering violent extremism (P/CVE) in their strategy to prevent and reduce armed conflict. The 2016 AU Master Roadmap of Practical Steps to Silence the Guns in Africa by 2020 makes commitments on both policy fields. ${ }^{1}$

1 With respect to P/CVE, these include operationalizing the AU Special Fund for Prevention and Combating of Terrorism and Violent Extremism; adopting human security and community involvement approaches to counter and prevent terrorism and violent extremism; deploying efforts to track down terrorists and their supporting networks; and enhancing national capacities for the prevention and combating of terrorism and violent extremism. See AU, Master 
Reliable information and analysis are critical for effectively dealing with such complex and multidimensional challenges as violent extremism and illicit arms flows. The AU Commission partnered with the Small Arms Survey to undertake a regional mapping of illicit weapons, culminating in the release of the report Weapons Compass: Mapping Illicit Small Arms Flows in Africa in Addis Ababa, July 2019. ${ }^{2}$ This Policy Note highlights the relevance of the report's findings and recommendations for P/CVE efforts, with an emphasis on arms trafficking across the continent's land borders.

\section{Relevance to Policy and Practice}

The overlap between small arms trafficking and violent extremism poses challenges for policymakers and practitioners in terms of inclusivity, coordination, evaluation of best practices, and balancing short- and long-term programmatic objectives.

Contrary to common perceptions that the bulk of illicit small arms and light weapons circulating in Africa is trafficked from other regions, the AU-Small Arms Survey report finds prominent sources of illicit weapons within the continent itself. Fifteen of the twenty-one African states that contributed information to the study ranked the (re-)circulation of arms across land borders as the main source of illicit arms. Evidence from peace support operations, UN embargo monitoring groups, and specialized research institutions also reveals that the majority of materiel confiscated in conflict zones is decades-old and was diverted from once licit stockpiles in the region before being smuggled and recirculated across borders. ${ }^{3}$

Another intraregional source of arms, although usually a small proportion of arsenals, is craft weapons ${ }^{4}$ produced by local artisans. Craft production of weapons occurs outside of state control, by hand, in small quantities, and with a reduced capability. Their low price makes craft firearms particularly attractive for self-protection and hunting. ${ }^{5}$ Yet craft firearms have also been found in the hands of violent extremist groups such as Boko Haram ${ }^{6}$ and are smuggled across borders. ${ }^{7}$

State security providers are often absent in remote border regions affected by arms trafficking. They can also be part of the problem through the actions of corrupt elements who engage in the illegal trade for personal profit. As a result, local communities seek to arm themselves for

Roadmap of Practical Steps to Silence the Guns in Africa by Year 2020 (Lusaka Master Roadmap 2016) (Addis Ababa: African Union (AU), 2016), 10-11.

2 AUC and Small Arms Survey, Weapons Compass: Mapping Illicit Small Arms Flows in Africa (Addis Ababa and Geneva: AUC and Small Arms Survey, 2019). The report is available in Arabic, English, French, and Portuguese on the Small Arms Survey's website: http://www.smallarmssurvey.org/about-us/highlights/2019/highlight-au-mapping.html.

3 This does not mean that new illicit transfers from other regions no longer take place at all. Recent transfers can comprise old, often surplus materiel. Moreover, the report notes that while they represent a small proportion of seized equipment, weapons and ammunition manufactured since 2010 have been documented in several African conflicts, pointing to recent illicit arms transfers, or to recent diversion of national stockpiles,. See: AUC and Small Arms Survey, Weapons Compass, 34-35.

4 "Craft production of small arms refers principally to weapons and ammunition that are fabricated largely by hand in relatively small quantities," for more on craft weapons, see: http://www.smallarmssurvey.org/weapons-and-markets/producers/craftproduction.html.

5 AUC and Small Arms Survey, Weapons Compass, 55-58; Matthias Nowak and Andre Gsell, Handmade and Deadly: Craft Production of Small Arms in Nigeria, Briefing Paper (Geneva: Small Arms Survey, 2018), 8.

6 Nowak and Gsell, Handmade and Deadly, 1.

7 AUC and Small Arms Survey, Weapons Compass, 55. 
protection and thus contribute to the increasing demand for illicit weapons. For instance, informal gold diggers in northern Niger resorted to illicit firearms possession to take security in their own hand, relying on converted imitation handguns smuggled from Libya. ${ }^{8}$ Members of pastoralist groups in Kenya, Somaliland, South Sudan, and Uganda have similarly acquired small arms for protecting cattle and property. ${ }^{9}$ The ensuing availability of these weapons can lead to the rapid escalation of local conflicts and deteriorating security perceptions, which further stimulates the illicit firearm market-local, national, and regional.

Illicit arms flows in Africa are closely connected to the livelihoods of populations in isolated border areas. These border communities often depend on informal cross-border trade to sustain their livelihoods. Cross-border small arms trafficking can be embedded in or use the same routes as other forms of legitimate trade. Consequently, when authorities crack down, they risk further marginalizing border communities and pushing them towards other dangerous and destabilizing criminal activities and trade routes. As research in the Sahel has shown, policies initially aimed at preventing and criminalizing human trafficking have led some traditional, legitimate migrant transporters to engage in drug trafficking, extremism, and insurgency. ${ }^{10}$

On the other hand, while counter-trafficking efforts can have unintended consequences, the issue of illicit arms flows often requires a robust response to counter the extremist violence that can stem from it. Analysis of the assault rifles recovered at multiple sites of attacks perpetrated by al-Qaeda-linked organizations in Burkina Faso, Côte d'Ivoire, and Mali in 2015-2016 suggests that some of the weapons were produced in the same factory in 2011 and originated from the same batch-as evidenced by their sequential serial numbers. ${ }^{11}$ Such cases illustrate how rapidly armed groups can move weapons across borders and use them in terrorist attacks. A particular policy challenge therefore lies in preventing and reducing armed groups' capacity to move deadly materiel across borders, while not marginalizing border communities to themselves become actors of trafficking and violent extremism.

\section{Recommendations}

The AU-Small Arms Survey study suggests two principal ways to link the policy fields of small arms control and P/CVE. From a prevention perspective, counter-trafficking interventions need to consider the livelihoods of border communities during implementation, while recognizing the shorter-term imperative of preventing violent extremist actors' access to deadly weaponry. Understanding, communicating, and acting upon these contradictions can improve the coordination of interventions, rationalize the use of scarce resources, and enhance policy impact.

8 Mathieu Pellerin, Beyond the Wild West: The Gold Rush in Northern Niger (Geneva: Small Arms Survey, 2017$), 8$.

9 See Manasseh Wepundi, et al., Evolving Traditional Practices: Managing Small Arms in the Horn of Africa and Karamoja Cluster (Geneva: Small Arms Survey, 2014).

10 See Jérôme Tubiana and Claudio Gramizzi, Tubu Trouble: State and Statelessness in the Chad-Sudan-Libya Triangle, Joint publication of the Human Security Baseline Assessment project, Security Assessment in North Africa project, and Conflict Armament Research, Working Paper No. 43 (Geneva: Small Arms Survey, 2017).

11 Holger Anders, Monitoring Illicit Arms Flows: The Role of UN Peacekeeping Operations, Security Assessment in North Africa Briefing Paper (Geneva: Small Arms Survey, 2018, 4-5); CAR (Conflict Armament Research), Investigating Cross-border Weapon Transfers in the Sahel (London: CAR. 2016). 
As few relevant interventions have been thoroughly assessed to date, further investigation is needed to develop practical guidance and tools in specific and mature policy areas and to coordinate initiatives more efficiently.

\section{Addressing knowledge gaps}

$\rightarrow$ Improve monitoring and analysis of illicit sources of weapons and ammunition for violent extremist actors. The report notes that international actors and NGOs produce much of the weapons-related intelligence currently available on the continent. States need to report more systematically to the existing weapons-related international ${ }^{12}$ and regional information exchange platforms. Under the framework of the Sustainable Development Goals, states are also encouraged to develop national indicators to monitor progress towards a reduction of illicit arms flows by 2030 (target 16.4). ${ }^{13}$

$\rightarrow$ Better understand the sources of insecurity, the role of border populations, and the gender dynamics in hard-to-access areas affected by small arms trafficking. The report notes instances where women actively participated in trafficking willingly or by lack of choice. Women and girls should not only be considered as victims of small arms-related violence, but also as those with active roles in trafficking, as well as agents for change with insight into stemming arms flows. In Libya, for instance, the UN Mine Action Service supported women to raise awareness in their communities of small arms-related risks and control measures through educational sessions, radio programs, and distributing material on safe storage and handling. ${ }^{14}$ Existing initiatives to engage with women in the search for and implementation of solutions need to be scaled up and more thoroughly assessed to leverage women as agents of change in reducing the security risk of small arms and light weapons to civilians and local communities. ${ }^{15}$

\section{Generating practical guidance}

$\rightarrow$ Implement joint border security arrangements. Border security initiatives should engage border communities in their efforts to stem trafficking. Existing efforts include stateled sub-regional cross-border security strategies, tripartite, quadripartite, and joint border commissions, ${ }^{16}$ as well as cross-border committees and projects facilitated by civil-society organizations. ${ }^{17}$ Creating a monitoring and evaluation framework for these initiatives is a

12 For instance, the Illicit Arms Records and Tracing Management System, see: INTERPOL, Illicit Arms Records and tracing Management System (iARMS).

13 See Glenn McDonald, Anna Alvazzi del Frate, and Moshe Ben Hamo Yeger, Arms Control 2.0: Operationalizing SDG Target 16.4 (Geneva: Small Arms Survey, 2017).

14 United Nations Support Mission in Libya (UNSMIL), "UNMAS Supports Libyan Women to Organize the First Small Arms and Light Weapons National Awareness Day in Libya," 2017.

15 AU Commission, Continental Results Framework: Monitoring and Reporting on the Implementation of the Women, Peace and Security Agenda in Africa (2018-2028) (Addis Ababa: African Union Commission, 2019).

16 See Sami Faltas, Controlling Small Arms: Practical Lessons in Civilian Disarmament and Anti-trafficking (Bonn: Bonn International Center for Conversion, 2018).

17 See, for instance, the work of the Danish Demining Group (DDG) at the Tunisian-Libyan border: DDG, "Tunisian-Libyan Border FactSheet." 
necessary step towards generating practical guidance in this critical operational domain.

$\rightarrow$ Organize civilian weapons collection initiatives. While international guidance on voluntary weapons surrender exists, ${ }^{18}$ the context-specific experiences of African states require further evaluation. The annual Amnesty Month, held every September to support the AU's Silence the Guns agenda, provides momentum for states and their partners to contextualize their approaches to weapons collection and identify best practices through adequate monitoring and evaluation. During Amnesty Month, AU member states promote and organize weapons surrender programs, while assuring anonymity and immunity to those surrendering their weapons. ${ }^{19}$

$\rightarrow$ Address craft production and converted firearms. Although craft production has been a challenge for decades ${ }^{20}$ and across the continent, good practices in this area remain poorly understood. While penalizing supplies to illicit networks, regional governments should provide alternative career paths to artisans and consider regularizing their activities for instance through censuses, registration campaigns, and the marking of products. States also need to clarify and harmonize their national regulations concerning readily convertible imitation firearms to prevent their illicit transformation into lethal weapons and trafficking, similar to policies in other regions. ${ }^{21}$

\section{Improving coordination}

$\rightarrow$ Coordinate small arms interventions at the strategic level. Myriad international and regional actors are involved in implementing small arms-related interventions on the continent, with emphasis on regions affected by conflict and violent extremism, such as the Sahel. Developing regional and national strategies and action plans on small arms can support more effective intergovernmental coordination of these efforts. These policy frameworks are more locally owned, and therefore effective, when elaborated through inclusive processes. Prioritization tools, such as the physical security and stockpile management (PSSM) matrix, can facilitate the development and coordination of such strategies. ${ }^{22}$

$\rightarrow$ Coordinate with other policy fields. Small arms control is closely interconnected with other policy areas, including security sector reform, the fight against transitional organized crime, women, peace, and security, and P/CVE. All these policy fields have their own strategic frameworks and implementation processes, yet to date there has

18 See, for instance, Module 05.40 in United Nations Office for Disarmament Affairs (UNODA), Modular Small-arms-control Implementation Compendium (MOSAIC).

$19 \mathrm{AU}$, "Africa Amnesty Month."

20 See Emmanuel Kwesi Aning, "The Anatomy of Ghana's Secret Arms Industry," in Nicolas Florquin and Eric G. Berman (eds.), Armed and Aimless: Armed Groups, Guns, and Human Security in the ECOWAS Region (Geneva: Small Arms Survey, 2005), 78-107).

21 For a review of initiatives and challenges in Europe, see Nicolas Florquin and Benjamin King, From Legal to Lethal: Converted Firearms in Europe (Geneva: Small Arms Survey, 2018).

22 Sarah Parker, Facilitating PSSM Assistance in the Sahel and Beyond: Introducing the PSSM Priorities Matrix (Geneva: Small Arms Survey, December 2016). 
been insufficient interaction and coordination with them at the national and local levels. There are obvious opportunities for researchers from these different sectors to better coordinate their research agendas and projects through participation in networks such as RESOLVE, for instance. Practitioners from relevant national commissions and civil society groups could identify opportunities to exchange experiences and coordinate their actions with the other communities of practice.

\section{Conclusion}

The challenges of tackling illicit arms flows in Africa should resonate strongly with P/CVE practitioners. On the one hand, counter-trafficking initiatives must prevent terrorist access to weapons in the short term. On the other hand, if undertaken without consideration for the livelihood of transit communities, security-centered counter-trafficking approaches are bound to be counter-productive in the long-run and may push these populations towards deeper criminality and, potentially, the facilitation of violent extremism. The synergies between the fields of small arms control and P/CVE are therefore critical, yet only tangentially explored. Both fields need more meaningful cooperation between researchers and practitioners. 


\title{
Suggested Further Readings, by topic
}

\author{
On the AU Master Roadmap
}

AU. Master Roadmap of Practical Steps to Silence the Guns in Africa by Year 2020 (Lusaka Master Roadmap 2016). African Union (AU). 2016. http://www.smallarmssurvey.org/fileadmin/docs/NInstruments/2018-AU-Silencing-the-Guns-Roadmap-ENG.pdf

\section{On Gender and Small Arms Control}

LeBrun, Emile, ed. Gender-responsive Small Arms Control: A Practical Guide. Geneva: Small Arms Survey, 2019. http://www.smallarmssurvey.org/fileadmin/docs/Q-Handbooks/HB-07-Gender/SAS-GLASSGender-HB.pdf

\section{On Illicit Flows and Violent Extremism}

AUC and Small Arms Survey. Weapons Compass: Mapping Illicit Small Arms Flows in Africa. Report. Addis Ababa and Geneva: African Union Commission (AUC) and Small Arms Survey. January 2019. http:// www.smallarmssurvey.org/fileadmin/docs/U-Reports/SAS-AU-Weapons-Compass.pdf

Duquet, Nils, ed. Triggering Terror: Illicit Gun Markets and Firearms Acquisition of Terrorist Networks in Europe. Brussels: Flemish Peace Institute, 2019. https://vlaamsvredesinstituut.eu/en/report/ triggering-terror-illicit-gun-markets-and-firearms-acquisition-of-terrorist-networks-in-europe/

MSC. Transnational Security Report. Cooperating Across Borders: Tackling Illicit Flows. Munich: Munich Security Conference (MSC), 2019. https://tsr.securityconference.de/assets/2019/Transnational Security/MSC Transnational Security Report.pdf

\section{On Armed Groups and Small Arms Control}

Florquin, Nicolas, with Pascal Bongard and Emilia Richard. "Options for Engagement: Armed Groups and Humanitarian Norms." In Small Arms Survey 2010: Gangs, Groups and Guns, 304-33. Cambridge: Cambridge University Press, 2010. http://www.smallarmssurvey.org/fileadmin/docs/A-Yearbook/2010/en/ Small-Arms-Survey-2010-Chapter-12-EN.pdf

de Tessières, Savannah. "Unit 10: Supporting the Development of Armed Actor Capacity for Weapons and Ammunition Management." In Planning Effective Weapons and Ammunition Management in a Changing DDR Context: A Handbook for Practitioners, 44-49. UNODA and UNDPKO, 2018. https:// www.un.org/disarmament/publications/more/ddr-handbook/ 


\section{Sources}

Anders, Holger. Monitoring Illicit Arms Flows: The Role of UN Peacekeeping Operations. Security Assessment in North Africa Briefing Paper. Geneva: Small Arms Survey. June 2018. http://www.smallarmssurvey.org/fileadmin/docs/T-Briefing-Papers/SANA-BP-Monitoring-Illicit-Arms-Flows-PKOs.pdf

Aning, Emmanuel Kwesi. "The Anatomy of Ghana's Secret Arms Industry." In Nicolas Florquin and Eric G. Berman (eds.), Armed and Aimless: Armed Groups, Guns, and Human Security in the ECOWAS Region. Geneva: Small Arms Survey. 2005, 78-107 http://www.smallarmssurvey.org/fileadmin/docs/D-Bookseries/book-01-Armed-and-Aimless/SAS-Armed-Aimless-Part-1-Chapter-03.pdf

AU. Master Roadmap of Practical Steps to Silence the Guns in Africa by Year 2020 (Lusaka Master Roadmap 2016). African Union (AU). 2016. http://www.smallarmssurvey.org/fileadmin/docs/NInstruments/2018-AU-Silencing-the-Guns-Roadmap-ENG.pdf

- - - "Africa Amnesty Month." https://au.int/en/africa-amnesty-month

AUC. Continental Results Framework: Monitoring and Reporting on the Implementation of the Women, Peace and Security Agenda in Africa (2018-2028.) Addis Ababa: African Union Commission (AUC). 2019. https://au.int/sites/default/files/documents/35958-doc-continental results framework wps. $\underline{\mathrm{pdf}}$

AUC and Small Arms Survey. Weapons Compass: Mapping Illicit Small Arms Flows in Africa. Report. Addis Ababa and Geneva: African Union Commission (AUC) and Small Arms Survey. January 2019. http:// www.smallarmssurvey.org/fileadmin/docs/U-Reports/SAS-AU-Weapons-Compass.pdf

CAR. Investigating Cross-border Weapon Transfers in the Sahel. London: Conflict Armament Research (CAR). 2016. https://www.conflictarm.com/download-file/?report id=2433\&file id=2434

DDG. "Tunisian-Libyan Border Factsheet." Danish Demining Group (DDG). https://danishdemininggroup. dk/media/4482868/ddg-tunisia-libya-factsheet apr-2018.pdf

Faltas, Sami. Controlling Small Arms: Practical Lessons in Civilian Disarmament and Anti-trafficking. Bonn: Bonn International Center for Conversion. 2018. https://www.bicc.de/uploads/tx bicctools/bicc Knowledge Note 32018 Controlling Small Arms.pdf

Florquin, Nicolas, and Benjamin King. From Legal to Lethal: Converted Firearms in Europe. Geneva: Small Arms Survey. April 2018. http://www.smallarmssurvey.org/fileadmin/docs/U-Reports/SAS-ReportEurope-Conversion.pdf

INTERPOL. Illicit Arms Records and tracing Management System (iARMS). https://www.interpol.int/en/ How-we-work/Databases/Illicit-Arms-Records-and-tracing-Management-System-iARMS

McDonald, Glenn, Anna Alvazzi del Frate, and Moshe Ben Hamo Yeger. 2017. Arms Control 2.0: Operationalizing SDG Target 16.4. Geneva: Small Arms Survey. October 2017. http://www.smallarmssurvey.org/ about-us/highlights/2017/highlight-bp-arms-control-2-0.html

Nowak, Matthias, and Andre Gsell. 2018. Handmade and Deadly: Craft Production of Small Arms in Nigeria. Geneva: Small Arms Survey. June 2018. http://www.smallarmssurvey.org/fileadmin/docs/T-BriefingPapers/SAS-BP-Nigeria-craft-weapons.pdf 
Parker, Sarah. Facilitating PSSM Assistance in the Sahel and Beyond: Introducing the PSSM Priorities Matrix. Issue Brief no. 18. Geneva: Small Arms Survey. December 2016. http://www.smallarmssurvey.org/fileadmin/docs/G-Issue-briefs/SAS-IB18-PSSM-Sahel.pdf

Pellerin, Mathieu. Beyond the Wild West: The Gold Rush in Northern Niger. Geneva: Small Arms Survey. June 2017. http://www.smallarmssurvey.org/fileadmin/docs/T-Briefing-Papers/SAS-SANA-BP-NigerGold.pdf

Tubiana, Jérôme, and Claudio Gramizzi. Tubu Trouble: State and Statelessness in the Chad-Sudan-Libya Triangle (Working Paper No. 43, Joint Publication of the Human Security Baseline Assessment Project, Security Assessment in North Africa Project, and Conflict Armament Research). Geneva: Small Arms Survey. 2017. http://www.smallarmssurvey.org/fileadmin/docs/U-Reports/SAS-SANA-Report-Lost-inTrans-nation.pdf

UNODA. Modular Small-arms-control Implementation Compendium (MOSAIC). United Nations Office for Disarmament Affairs (UNODA). https://www.un.org/disarmament/convarms/mosaic/

UNSMIL. "UNMAS Supports Libyan Women to Organize the First Small Arms and Light Weapons National Awareness Day in Libya." United Nations Support Mission in Libya (UNSMIL) December 2017. https:// unsmil.unmissions.org/unmas-supports-libyan-women-organize-first-small-arms-and-light-weaponsnational-awareness-day-libya

Wepundi, Manasseh, et al. Evolving Traditional Practices: Managing Small Arms in the Horn of Africa and Karamoja Cluster. Geneva: Small Arms Survey. June 2014. http://www.smallarmssurvey.org/fileadmin/ docs/G-Issue-briefs/SAS-AA-IB3-Traditional-Practices.pdf 
RESOlVe Policy Note \Community-Based Armed Groups Series $\mid 10$ 
ReSOlVe Policy Note \Community-Based Armed Groups | 11 


\section{About the Note}

Author: Nicolas Florquin, Research Coordinator, Small Arms Survey.

The views expressed in this publication are those of the author. They do not necessarily reflect the views of the RESOLVE Network, the U.S. Institute of Peace, or any entity of the U.S. government.

\section{RESOLVE NETWORK}

better research.informed practice.improved policy on violent extremism.

www.resolvenet.org

(9) in. 